\title{
Virotherapy as a Potential Therapeutic Approach for the Treatment of Aggressive Thyroid Cancer
}

\author{
Anna Maria Malfitano ${ }^{\circledR}$, Sarah Di Somma, Nella Prevete and Giuseppe Portella * \\ Dipartimento di Scienze Mediche Traslazionali, Università Federico II Napoli, URT "Genomic of Diabetes" of \\ Institute of Experimental Endocrinology and Oncology "G. Salvatore”, National Council of Research (CNR), \\ 80131 Naples, Italy; annamaria.malfitano@unina.it (A.M.M.); sarah_ds@hotmail.it (S.D.S); \\ nella.prevete@unina.it (N.P.) \\ * Correspondence: portella@unina.it; Tel.: +39-081-746-3056
}

Received: 18 September 2019; Accepted: 3 October 2019; Published: 10 October 2019

\begin{abstract}
Virotherapy is a novel cancer treatment based on oncolytic viruses (OVs), which selectively infect and lyse cancer cells, without harming normal cells or tissues. Several viruses, either naturally occurring or developed through genetic engineering, are currently under investigation in clinical studies. Emerging reports suggesting the immune-stimulatory property of OVs against tumor cells further support the clinical use of OVs for the treatment of lesions lacking effective therapies. Poorly differentiated thyroid carcinoma (PDTC) and anaplastic thyroid carcinoma (ATC), have a poor prognosis and limited treatment options. Therefore, several groups investigated the therapeutic potential of OVs in PDTC/ATC models producing experimental data sustaining the potential clinical efficacy of OVs in these cancer models. Moreover, the presence of an immunosuppressive microenvironment further supports the potential use of OVs in ATC. In this review, we present the results of the studies evaluating the efficacy of OVs alone or in combination with other treatment options. In particular, their potential therapeutic combination with multiple kinases inhibitors (MKIs) or immune checkpoint inhibitors are discussed.
\end{abstract}

Keywords: oncolytic virus; immunotherapy; anaplastic and poorly differentiated thyroid carcinoma

\section{Introduction}

Thyroid carcinoma (TC) is the most common endocrine malignancy. Its incidence is estimated to be $1-2$ million per year [1,2]. Papillary thyroid carcinoma (PTC) comprises $80-85 \%$ of all thyroid neoplasms, follicular thyroid carcinoma (FTC) accounts for 10-15\% of cases, and PDTC and ATC are the less common histotypes. PTC and FTC have an excellent survival rate (98\%) and a good prognosis, with a low recurrence rate $(5 \%)$, whereas PDTC and ATC have a poor prognosis and account for most of the TC related deaths. ATC and PDTC are tumors that lose, completely or partially, the typical features of their original follicular cells. Genetic analysis of these tumors demonstrated that ATC, and to a lesser extent PDTC, accumulate several different oncogenic alterations, TERT oncogene and TP53 tumor suppressor gene are the most frequently altered genes. Other pathways like MAPK and PI3K-AKT are altered in these tumors with mutation in BRAF, RAS, AKT, PTEN, and PIK3CA [3]. Undifferentiated TCs are characterized by a rapid tumor growth, trachea obstruction with respiratory distress, and frequent distant metastases, with a survival time of six months from the diagnosis.

For these forms multimodal treatment, surgery, chemotherapy, and radiation obtained a very limited success $[1,2,4,5]$. Multiple kinase inhibitors (MKIs) targeting the signaling pathways oncogenically activated in TC (i.e., RAS, BRAF, MEK, MAPK) are currently used to treat the advanced forms, exerting cytostatic effects on TC cells. However, the development of tumor resistance to these MKIs has limited their clinical benefits [6,7] and not increased the survival rate for ATC or PDTC. 
The need for more effective therapies has prompted the investigation toward different approaches including virotherapy with OVs that selectively infect and lyse cancer cells, without harming normal cells or tissues [8,9]. Studies performed in experimental models of ATC sustain the potential clinical efficacy of OVs in the treatment of ATC/PDTC in combination with different agents. In this review, we focused on reports dealing with the use of OVs in TC.

\section{Virotherapy and OVs}

The hypothesis that cancer cells are vulnerable to viral infections is very old. In early 1900s, the observation of an Italian gynecologist, Dr. Di Pace and several others, reported cancer remission after viral infections [10]. Thus, virotherapy was hypothesized to be useful against cancer and some clinical trials were performed between 1950 and 1970 [11]. However, severe side effects and treatment related deaths were observed, thus the use of viruses for cancer treatment was considered unsafe.

In 1990s, the research on OVs revived owing to a better knowledge of viral gene functions, a better understanding of the molecular alterations in cancer cells, and the availability of technologies for the manipulation of viral genomes. Two studies had a crucial role for the development of this research area:

i) In 1991, a modified Herpes Simplex Virus 1 (HSV-1) with reduced neurotoxicity and with a mutation in the thymidine kinase gene was shown to replicate selectively in cancer cells [12];

ii) In 1996, dl1520 (a.k.a. ONYX-015), an oncolytic adenovirus (Ads) with the deletion of E1B55K gene was described. E1B55K product binds and degrades p53. In most neoplastic cells, the functional inactivation of p53 complements E1B55K-deletion or viral mRNA nuclear export $[13,14]$. dl1520 has been evaluated in 18 phase I and II clinical trials confirming its safety [15], however a phase III clinical trial has not been completed because of changes in the priority choice of the company [16].

Since then, different strategies to obtain tumor selectivity or to increase the efficacy of OVs have been exploited, and different viral strains tested for tumor selectivity. An increasing number of viruses are under investigation in clinical studies [17]; three viruses are currently approved for cancer treatment.

Rigvir, a wildtype non-pathogenic enteric cytopathic human orphan type 7 (ECHO-7) was approved only by the Latvian regulatory agency for the treatment of melanoma $[18,19]$. This virus has not met the required standard regulation for European or US approval, further studies are in progress to better evaluate its therapeutic potential [20].

In 2005, H101, an Ads with the same deletion of $d l 1520$, was approved by China's State Food and Drug administration for the treatment of head and neck carcinoma on the basis of the results obtained in a Phase III trial [21,22].

In 2015, EMA and FDA approved T-VEC (talimogene laherparepvec, Amgen, Inc., Thousand Oaks, CA, USA), a modified HSV-1 expressing GM-CSF [23]. T-VEC is now included as a routine treatment option for unresectable early metastatic melanoma, but it has also been used as neo-adjuvant therapy and in other cancer types [24].

Currently, other OVs are being tested in clinical trials (https:/clinicaltrials.gov/ClinicalTrials.gov: NCT002705;NCT0320601, NCT03004183; etc.) and although it is likely that not all of them will be effective, the number of OVs approved for cancer treatment is expected to increase in future.

\section{Direct Effects of OVs}

The tumor selectivity of OVs can be either natural or obtained by viral genome manipulation. On this basis, OVs are divided in two groups: natural or genetically modified.

The natural OVs have innate selectivity toward cancer cells, exploiting the aberrant signaling pathways that sustain cancer growth [25].

Genetically modified OVs are viruses whose genome has been manipulated, to selectively replicate in neoplastic cells. To obtain a selective viral infection/replication in tumor cells, the most common 
strategies focused on restricting the expression of essential viral-proteins by using cancer-specific promoters, or deleting viral proteins that prevent apoptosis in healthy cells $[25,26]$. Other approaches include the selective control of replication via viral gene inactivation, transcriptional targeting, microRNA targeting sequences [17].

Other modifications include the insertion of therapeutic genes in order to generate "armed" OVs with the aim to improve therapeutic efficiency and selectivity. Some modifications were made to improve the direct cytotoxic effects of viruses on cancer cells. This class of modifications includes the insertion in the viral genome of therapeutic transgenes to increase release, spread, and to reduce off-target effects on normal cells. Other viruses have modification of the capsid to improve the therapeutic window. The last generation of armed OVs combines OVs with immune modulators in order to enhance the efficiency of immune response and of OVs. These last OVs are engineered to express, cytokines or chemokines [27]. Among several others (i.e., reporter genes, radio-sensitizers, prodrug convertases), OVs have been engineered also to express anti-angiogenic genes as transgenes to target tumor vasculature [28]. Cytokines and chemokines can stimulate simultaneously different immune cells favoring immune response against cancer cells. Several OVs expressing these molecules have been generated.

The capability of OVs to selectively replicate in and lyse cancer cells sparing normal cells not only relies on the selective replicative activity (natural or obtained) of the virus, but also on the reduced anti-viral response of neoplastic cells. Indeed, in normal cells viral infection elicits the release of interferons (IFNs), produced following the detection of viral RNA, DNA, or proteins by intracellular pathogen recognition receptors (PRRs). IFN signaling pathway activates the expression of effector genes known as interferon-stimulated genes (ISGs). The expression of ISGs aims to the clearance of the viral infection [28,29]. Neoplastic cells have abnormal IFN pathways. The loss of IFN type I signaling allows cancer cells to circumvent the growth inhibitory effects mediated by IFN $[30,31]$ and mediates immune evasion of tumor [32]. IFN pathway abnormalities are more frequent in advanced aggressive lesions and therefore OVs might display a higher proliferative potential in more aggressive cancers [33]. Overall, IFN pathway abnormalities favor cancer cell survival and immune-escape, but make neoplastic cells highly susceptible to viral infection.

Other alterations of anti-viral response also contribute to OV selectivity for neoplastic cells. Protein kinase $\mathrm{R}$ (PKR) pathway [34] is critical for intrinsic cellular anti-viral response. The recognition of viral elements by Toll-like receptor (TLR) activates the downstream pathways, leading to the activation of PKR [35]. In normal cells, phosphorylated PKR inhibits protein synthesis with the consequent block of viral replication and propagation [36]. To support uncontrolled proliferation in neoplastic cells, the PKR pathway is not functional, thus allowing viral replication. Mutations of RAF or NRAS, frequently observed in TC, constitutively activate MAP kinase pathway, which suppresses PKR activation [37,38]. In TCs, a reverse correlation between PKR and Ki-67 expression has been observed, indicating that TC cells might be susceptible to OV infections [39].

\section{Indirect Effects of OVs}

Indirect effects of OVs are mainly associated with the capability of OVs to stimulate an anti-tumor immune response, therefore, OVs are also considered as immunotherapeutic agents. The main indirect effects of OVs are listed below [40], and reported more in detail in the next paragraphs:

i) Activation of danger signals and immunogenic cell death (ICD) pathways with the subsequent stimulation of innate or adaptive immune responses against cancer cells.

ii) Release of antigens derived from both the virus and cancer cells, leading to immune activation also against non-infected tumor cells.

iii) Release by infected dying cells of several cytokines into the local environment (i.e., IFNs, tumor necrosis factor-alpha and interleukins) that further promote immune response and reshape the pro-tumor microenvironment (TME) toward an inflammatory and anti-tumor phenotype.

iv) Inhibition of tumor angiogenesis because of the interaction of OVs with TME. 


\subsection{Activation of ICD Pathways by OVs}

Cell death pathways activated by OV infection are highly immunogenic [41,42] and include pyroptosis (caspase-1-dependent cell death), autophagic cell death, ICD, necrosis, necroptosis, and apoptosis, although the latter is essentially immunoquiescent. ICD is defined as a form of regulated cell death sufficient to activate an adaptive immune response in an immunocompetent host [43]. ICD results in the release of danger associated molecular patterns (DAMPs) initiating immune response. Three DAMPs are considered as biochemical hallmarks of ICD: calreticulin, HMGB1, and ATP. Calreticulin (CRT) exposed on the surface, or released in the surrounding milieu, of a dying cell acts as a phagocytic signal to trigger an innate immune response [44,45]. HMGB1 triggers an inflammatory response via interaction with specific receptors [46]. The extracellular release of ATP acts as a potent chemoattractant of immune cells.

Antigen presenting cells (APCs), such as dendritic cells (DCs) and macrophages, in TME recognize the danger signals of ICD, generating an immune response and the production of alpha and beta interferons. Cytokines released by activated DCs contribute to the activation of natural killer (NK) cells [47]. Furthermore, macrophages conditioned toward an M1-phenotype by IFN signals, directly contribute to tumor cell killing.

The ability of OVs to sustain ICD has been associated to their capability to release DAMPs or soluble tumor-associated antigens that in turn induce innate and adaptive immune responses [48]. The activation of ICD has been reported for OVs of different origin [49-51]. Indeed, in culture Ads [52], measles virus [53], oncolytic reovirus [54], and coxsackievirus B3 [55] were shown to induce all the key features of ICD (i.e., surface expression of calreticulin, higher levels of extracellular ATP and HMGB1) in several cancer models [56]. These evidences were also confirmed in vivo in immunocompetent mice models demonstrating the ability of Ads to increase the infiltration, in ectopic tumor transplantations, of macrophages and $\mathrm{T}$ cells with an anti-tumor/cytotoxic phenotype [52]. Although defective of adaptive immune system also in nude mice, coxsackievirus B3 OV displayed the ability to recruit an increased number of innate immune cells in xenotransplants [55].

Several studies both in preclinical models and in human patients approached the possibility to improve the immunogenicity of cancer cells by the combination of OVs with drugs able to initiate ICD. hTert-Ads (human telomerase reverse transcriptase promoter-regulated Ads) in combination with the proteasome inhibitor bortezomib enhanced endoplasmic reticulum (ER) stress and ICD thus sustaining in vivo anti-tumor activity in hepatocellular carcinoma [57]. Similarly, a preclinical murine breast cancer model was used to verify that combination of oncolytic HSV-1 with mitoxantrone, a drug known to induce ICD, enhanced therapeutic efficacy of the drug by abolishing tumor immune tolerance [58]. In chemotherapy refractory pancreatic carcinoma patients, the administration of Ads in combination with temozolomide and cyclophosphamide prolonged the disease control and survival. The increased survival was significantly associated to an increase in serum HMGB1 levels in turn associated to an increased anti-tumor T-cell response [59]. Therefore, several reports point at the possibility to combine OVs, well-known inducers of ER stress, to drugs that are suboptimal inducers of ICD in order to improve the anti-tumor immune response.

\subsection{OV Activity on Endothelial Cells and Cancer-Associated Fibroblasts}

The indirect effects of OVs on cancer cells are not only mediated by immune cell conditioning, but are also due to effects on other cellular elements such as cancer-associated fibroblasts (CAFs) and endothelial cells. CAFs sustain tumor growth, angiogenesis, epithelial-to-mesenchymal transition (EMT), and promote tumor resistance to chemotherapeutic drugs [60,61].

Transforming growth factor-beta1 (TGF beta-1) is a key mediator in reshaping the phenotype of fibroblasts toward the CAFs phenotype, though TGF-beta suppresses IFN signaling [33]. This makes CAFs more susceptible to OV infection in comparison to normal fibroblasts because of reduced type I IFN. The susceptibility of cancer cells to OV infection has been demonstrated to increase when co-cultured with CAFs. Ilkow CS and coll. demonstrated that FGF2 produced by CAFs enhanced 
OV replication in cancer cells and reduced the anti-viral proteins produced by cancer cells in culture. Similarly, intra-tumor FGF2 or co-injection of CAFs increased OV replication in several xenograft models. Thus, the cross-talk between cancer cells and CAFs in the TME is crucial to determine OV sensitivity [62].

OVs exert an anti-angiogenic effect by acting on endothelial cells in TME [40]. Indeed, OVs target tumor-associated endothelial cells leading to a rapid destruction of the tumor vasculature and loss of perfusion within the tumor. It has been reported that vascular endothelial growth factor (VEGF) secretion by cancer cells makes endothelial cells susceptible to OV infection by reducing the anti-viral response. The cross talk between VEGF-driven pathways and interferon further inhibits the anti-viral response of endothelial cells [63]. Other mechanisms mediating disruption of tumor blood flow by OVs have been described, such as viral replication in tumor-associated endothelial cells [64]. OVs have been also reported to decrease the secretion of pro-angiogenic factors such as VEGF or IL-8 [65]. These effects can be exploited for synergistic combination with different anti-tumor agents [11].

\section{OV Activity in TC Models}

Several studies reported the efficacy of OV in TC experimental models either as single agents or in combination with anti-neoplastic drugs [66], main preclinical data are summarized in Tables 1 and 2.

Table 1. DNA OVs.

\begin{tabular}{|c|c|c|c|c|c|c|}
\hline $\begin{array}{l}\text { Family and } \\
\text { Type Species }\end{array}$ & Name & $\begin{array}{l}\text { Viral Genetic } \\
\text { Modification }\end{array}$ & $\begin{array}{l}\text { Exploited } \\
\text { Cancer } \\
\text { Pathway }\end{array}$ & $\begin{array}{c}\text { Combination } \\
\text { with Other } \\
\text { Therapeutics }\end{array}$ & Refs & Models \\
\hline \multirow[t]{6}{*}{$\begin{array}{l}\text { Adenoviridae, } \\
\text { Human } \\
\text { Adenovirus C }\end{array}$} & $\begin{array}{c}d l 1520 \\
\text { (ONYX-015) }\end{array}$ & $\begin{array}{l}\text { E1B-55kDa } \\
\text { deletion }\end{array}$ & p53 deficiency & $\begin{array}{l}\text { Doxorubicin, } \\
\text { Paclitaxel } \\
\text { Ionizing } \\
\text { Radiation (IR) } \\
\text { Lovastatin }\end{array}$ & $\begin{array}{l}66 \\
68 \\
72\end{array}$ & $\begin{array}{l}\text { in vitro } \\
\text { and mouse } \\
\text { models }\end{array}$ \\
\hline & $d l 922-947$ & E1A-CR2 deletion & $\mathrm{pRb}$ deficiency & $\begin{array}{c}\text { Bevacizumab } \\
\text { AZD1152 } \\
\text { IR } \\
\text { Olaparib }\end{array}$ & $\begin{array}{l}73 \\
82 \\
83 \\
84\end{array}$ & $\begin{array}{l}\text { in vitro } \\
\text { and mouse } \\
\text { models }\end{array}$ \\
\hline & HILMI & $\begin{array}{c}\mathrm{TCF} / \beta \text {-catenin } \\
\text { responsive promoter } \\
\text { insertion }\end{array}$ & $\begin{array}{c}\text { Wnt } / \beta \text {-catenin } \\
\text { hyper-activation }\end{array}$ & $\mathrm{NO}$ & 93 & $\begin{array}{l}\text { in vitro } \\
\text { and mouse } \\
\text { models }\end{array}$ \\
\hline & ONYX-411 & $\begin{array}{l}\text { E2F promoter } \\
\text { insertion controls E1A } \\
\text { and E4 gene } \\
\text { expression } \\
\text { E1A-CR2 deletion }\end{array}$ & $\begin{array}{c}\text { E2F } \\
\text { hyper-expression } \\
\text { pRb deficiency }\end{array}$ & $\mathrm{NO}$ & 94 & $\begin{array}{l}\text { in vitro } \\
\text { and mouse } \\
\text { models }\end{array}$ \\
\hline & $d l 309$ & $\begin{array}{c}\text { E3 } 10.4 \mathrm{~K}, 14.5 \mathrm{~K}, 14.7 \\
\text { K deletion } \\
\text { E3 } 6.7 \mathrm{~K} \text { mutation }\end{array}$ & & NO & 95 & in vitro \\
\hline & $\begin{array}{c}\text { VB-111 } \\
\text { (non-replicative) }\end{array}$ & $\begin{array}{l}\text { E1 deletion and } \\
\text { insertion of Fas-c gene } \\
\text { under a modified } \\
\text { PPE-1 promoter }\end{array}$ & & $\mathrm{NO}$ & 120 & $\begin{array}{l}\text { mouse } \\
\text { models }\end{array}$ \\
\hline \multirow[t]{2}{*}{$\begin{array}{c}\text { Poxviridae, } \\
\text { Vaccinia Virus }\end{array}$} & VACV & EGFP insertion & $\begin{array}{c}\text { AKT } \\
\text { hyperactivation }\end{array}$ & NO & 99 & in vitro \\
\hline & GLV-1h68 & $\begin{array}{c}\text { Insertion of RUC-GFP, } \\
\beta \text {-galactosidase, } \\
\beta \text {-glucuronidase into } \\
\text { F14.5L, J2R and A56R } \\
\text { loci of the viral } \\
\text { genome, respectively }\end{array}$ & $\begin{array}{c}\mathrm{AKT} \\
\text { hyperactivation }\end{array}$ & $\mathrm{NO}$ & 101-103 & $\begin{array}{l}\text { in vitro } \\
\text { and mouse } \\
\text { models }\end{array}$ \\
\hline
\end{tabular}


Table 1. Cont.

\begin{tabular}{|c|c|c|c|c|c|c|}
\hline $\begin{array}{l}\text { Family and } \\
\text { Type Species }\end{array}$ & Name & $\begin{array}{l}\text { Viral Genetic } \\
\text { Modification }\end{array}$ & $\begin{array}{l}\text { Exploited } \\
\text { Cancer } \\
\text { Pathway }\end{array}$ & $\begin{array}{l}\text { Combination } \\
\text { with Other } \\
\text { Therapeutics }\end{array}$ & Refs & Models \\
\hline $\begin{array}{l}\text { Poxviridae, } \\
\text { Tanapox Virus } \\
\text { Myxoma Virus }\end{array}$ & $\begin{array}{l}\text { TANV } \\
\text { MYXV }\end{array}$ & EGFP insertion & $\begin{array}{c}\text { AKT } \\
\text { hyperactivation }\end{array}$ & NO & 99 & in vitro \\
\hline \multirow[t]{3}{*}{$\begin{array}{l}\text { Herpesviridae, } \\
\text { Human } \\
\text { herpesvirus } 1\end{array}$} & NV1023 & $\begin{array}{l}\text { HSV2 genes (US2-2 } \\
\text { and US2-5) insertion } \\
\text { in the UL/S junction. } \\
\text { ICP10, ICP4, } \gamma 34.5 \\
\text { gene deletion. } \\
\text { lacZ gene insertion } \\
\text { into US10-12 locus. }\end{array}$ & $\begin{array}{l}\text { Defective PKR } \\
\text { signaling }\end{array}$ & NO & 108 & $\begin{array}{l}\text { mouse } \\
\text { models }\end{array}$ \\
\hline & G207 & $\begin{array}{c}\gamma 34.5 \text { deletion } \\
\text { UL39 inactivation by } \\
\text { insertion of lacZ gene }\end{array}$ & $\begin{array}{l}\text { Defective PKR } \\
\text { signaling }\end{array}$ & $\begin{array}{l}\text { Paclitaxel and } \\
\text { Adriamycin }\end{array}$ & 109 & $\begin{array}{l}\text { in vitro } \\
\text { and mouse } \\
\text { models }\end{array}$ \\
\hline & G47 $\triangle$ & $\begin{array}{l}\gamma 34.5, \text { ICP47 and US11 } \\
\text { promoter deletions } \\
\text { UL39 inactivation by } \\
\text { insertion of lacZ gene }\end{array}$ & $\begin{array}{l}\text { Defective PKR } \\
\text { signaling }\end{array}$ & NO & 110 & $\begin{array}{l}\text { in vitro } \\
\text { and mouse } \\
\text { models }\end{array}$ \\
\hline
\end{tabular}

Table 2. RNA OVs.

\begin{tabular}{|c|c|c|c|c|c|c|}
\hline $\begin{array}{c}\text { Family and Type } \\
\text { Species }\end{array}$ & Name & $\begin{array}{l}\text { Viral Genetic } \\
\text { Modification }\end{array}$ & $\begin{array}{l}\text { Exploited } \\
\text { Cancer } \\
\text { Pathway }\end{array}$ & $\begin{array}{c}\text { Combination } \\
\text { with other } \\
\text { therapeutics }\end{array}$ & Refs & Model \\
\hline \multirow[t]{2}{*}{$\begin{array}{c}\text { Paramyxoviridae } \\
\text { (Negative ssRNA), } \\
\text { Measles Virus (MV) }\end{array}$} & MV-Edm & $\begin{array}{l}\text { Live attenuated } \\
\text { Edmonston B } \\
\text { strain }\end{array}$ & $\begin{array}{l}\text { CD46 expression } \\
\text { on cell surface }\end{array}$ & & $104-106$ & $\begin{array}{l}\text { in vitro and } \\
\text { mouse } \\
\text { models }\end{array}$ \\
\hline & MV-NIS & $\begin{array}{l}\text { Human NIS } \\
\text { insertion }\end{array}$ & $\begin{array}{l}\text { CD46 expression } \\
\text { on cell surface }\end{array}$ & $\begin{array}{l}\text { Radio iodine } \\
\text { therapy }\left({ }^{131} \mathrm{I}\right)\end{array}$ & 107 & $\begin{array}{l}\text { in vitro and } \\
\text { mouse } \\
\text { models }\end{array}$ \\
\hline $\begin{array}{c}\text { Paramyxovirus } \\
\text { (ssRNA), Newcastle } \\
\text { disease virus (NDV) }\end{array}$ & NDV/FMW & $\begin{array}{l}\text { Unmodified } \\
\text { oncolytic NDV, } \\
\text { FMW strain }\end{array}$ & $\begin{array}{c}\text { RAS } \\
\text { hyperactivation }\end{array}$ & $\mathrm{NO}$ & 117 & $\begin{array}{c}\text { in vitro, } \\
\text { mouse } \\
\text { models and } \\
\text { clinical } \\
\text { studies }\end{array}$ \\
\hline $\begin{array}{l}\text { Paramyxovirus } \\
(s s R N A) \text {, Sendai } \\
\text { virus }\end{array}$ & BioKnife & $\begin{array}{l}\text { M gene deletion } \\
\text { and insertion of } \\
\text { GFP gene } \\
\text { Insertion of uPA } \\
\text { cleavage site in } \\
\text { F gene }\end{array}$ & uPA activity & NO & 119 & $\begin{array}{l}\text { in vitro and } \\
\text { mouse } \\
\text { models }\end{array}$ \\
\hline $\begin{array}{c}\text { Reoviridae (dsRNA), } \\
\text { Reovirus }\end{array}$ & REOLYSIN & $\begin{array}{l}\text { Unmodified } \\
\text { oncolytic } \\
\text { Reovirus }\end{array}$ & $\begin{array}{l}\text { Defective (PKR) } \\
\text { signaling } \\
\text { RAS activation } \\
\text { Defective } \\
\text { antiviral } \\
\text { response } \\
\text { Cellular stress }\end{array}$ & $\begin{array}{l}\text { Low dose IR } \\
\text { (PHASE II study } \\
\text { for advanced } \\
\text { cancer, partial } \\
\text { response in one } \\
\text { patient with } \\
\text { thyroid } \\
\text { carcinoma) }\end{array}$ & 54 & $\begin{array}{l}\text { in vitro and } \\
\text { mouse } \\
\text { models }\end{array}$ \\
\hline
\end{tabular}

\subsection{Oncolytic Ads Effects}

Oncolytic Ads are the most studied OVs in ATC models. Ads can be easily produced and are suitable for manipulation to enhance their oncolytic activity. To date, a number of genetically modified oncolytic Ads have been developed and proved to be highly efficient.

$d l 1520$, the first OV used against TC cell lines and in ATC xenografts, showed efficacy as a single agent [67]. However, in cell cultures, the combination with paclitaxel or doxorubicin 
induced cell death more efficiently than the single treatments. Indeed, its combination with ionizing radiation (IR) delayed the growth of ATC xenograft [68]. dl1520 has been also used in combination with lovastatin, a cholesterol-lowering drug that inhibits HMG-CoA reductase and consequently farnesylation and geranylgeranylation causing inactivation of Ras and Rho [69]. Lovastatin used alone exerts anti-proliferative effects in rat thyroid cells and induces apoptosis in human thyroid cells $[69,70]$. Moreover, Rho B is a relevant molecular target in ATC therapy [71]. The combination with dl1520 improved viral replication and cytotoxicity, enhancing ATC cell death [72]. This study is one of the first report showing that drugs inhibiting p21 RAS activity cooperate with OVs. Although several experimental studies supported the efficacy of $d l 1520$ in ATC cells, these effects were not confirmed by clinical studies, thus novel OVs were generated $[73,74]$ and tested in ATC models.

d1922-947 is a second generation Ads presenting a 24-bp deletion in the E1A-conserved region 2 (CR2) [75] that is essential to bind and inactivate the $\mathrm{pRb}$ tumor suppressor protein. This mutation renders the virus unable to trigger S-phase entry in normal cells, whereas it can replicate only in cells with an aberrant G1-S checkpoint, a defect detected in the most of human cancers including ATC e PDTC [76]. In human cancer cells and also in ATC cells, dl922-947 presents a superior cell killing with respect to $d l 1520$ [73,77-81]. In ATC experimental models $d 1922-947$ has been extensively studied as a single agent [73] and also in combination with other drugs [73,82-84]. In particular, it was combined with bevacizumab, a humanized anti-VEGF antibody, to improve viral distribution and diffusion that is usually compromised by the abnormal tumor vascular structure and by the increased interstitial tumor pressure [85]. In ATC xenografts, the treatment with bevacizumab followed by virus administration normalized the vascular structure decreasing interstitial pressure, thus favoring a more efficient viral distribution within the tumor $[73,86]$.

The effect of $d 1922-947$ in ATC cells is usually associated with increase of DNA content $(>4 N)$ and accumulation in G2/M phase [84], likely because of abrogation of multiple cell cycle checkpoints by viral proteins. Thus, Libertini et al. hypothesized that the pharmacological block of the mitotic checkpoints could enhance dl922-947 efficacy. Considering that the mitotic kinase Aurora B is overexpressed in ATC cells and its inhibition reduces tumor growth [87], the combination with AZD1152, a specific Aurora B kinase inhibitor was investigated. AZD1152 induced G2/M phase accumulation, polyploidy, and cell death by mitotic catastrophe, its combination with dl922-947 showed additive or synergistic effects and induced a significant block of tumor growth [82].

To hinder viral infection, infected cells process viral DNA as damaged genetic material through the DNA damage response (DDR). To counteract DDR effects, viruses attempt to degrade or mislocalize key players of DDR [88-90]. In ATC cells, Passaro et al. demonstrated that dl922-947 triggers an inefficient DDR, since it induced accumulation of $\mathrm{X}_{\mathrm{H} 2 \mathrm{AX}}$, a marker of DNA damage [83].

The use of IR known to induce DNA damage was explored in association with dl922-947, when irradiation was administered prior to viral infection a synergistic tumor cell killing was observed [83]. dl922-947 was also used in association with KU55933, a specific-inhibitor of ATM kinase, this combination inhibited DDR enhancing the effects of $11922-947$. The same group studied the activity of $d 1922-947$ against other DNA repair pathways. In particular, poly (ADP-ribose) polymerase 1 (PARP-1) is a key mediator in base excision repair (BER) pathway and is also involved in other DNA damage repair processes, including the repair of DNA double strand breaks [91,92]. dl922-947 infection induces PARP-1 activation in ATC cells. Passaro et al. used Olaparib, a specific PARP inhibitor, in association with d $1922-947$; the combined effect greatly enhanced DNA damage accumulation and cell death in ATC cells [84]. These reports suggest that the exploitation of dl922-947 effects on DNA repair pathways might be of relevance to develop more effective therapeutic strategies against ATC.

Nonetheless, the impact of $d 1922-947$ as single agent on the pro-tumorigenic ATC microenvironment was also evaluated. dl922-947 significantly reduced the production of inflammatory or pro-tumor cytokines and chemokines like IL-8/CXCL8 and MCP-1/CCL2 by infected ATC cells. Indeed, a reduced NF-KB p65 binding to IL-8 and CCL2 promoters in ATC cells infected with d1922-947 was demonstrated. The decrease of IL-8 secretion impaired the cell motility in vitro and tumor angiogenic response in vitro 
and in vivo. The decrease of the monocyte-attracting chemokine MCP-1/CCL2 reduced monocyte chemotaxis in vitro and tumor macrophage density in vivo. In ATC xenografts, dl922-947 induced the switch from M2 tumor-promoting macrophages toward a pro-inflammatory M1 phenotype. A high viral dose elicited tumor eradication in $40 \%$ of the mice after 2 weeks of treatment and the animals remained tumor-free until the end of the experiment. However, these effects were observed in immunocompromised animals, allowing only the evaluation of the innate response stimulated by the viral infection [65]. The confirmation in immune competent animals or in a more sophisticated immune competent model such as the humanized model, bearing the human immune system, could be useful. Nevertheless, these data clearly show that $d 1922-947$ exerts an anti-tumor innate response and its direct effect on ATC cells is sufficient to modulate the TME.

Overall, the data obtained with $d 1922-947$ sustain the possibility to use this virus or a more advanced version in ATC/PDTC patients.

Other Ads have been tested in ATC models. A fraction of undifferentiated TC presents mutations in beta-catenin gene [1]. This feature has been exploited to develop "HILMI," an oncolytic Ads replicating in cells with an active Wnt/beta-catenin. In this virus a TCF response element drives the expression of adenoviral genes E1A and E1B, allowing viral replication in the fraction of ATC and PDTC cells with active Wnt/beta-catenin pathway. HILMI efficiently killed TC cells and prolonged the survival of mice with ATC xenografts [93].

In the oncolytic Ads ONYX-411, E2F promoter controls the expression of E1A and E4 genes. This conditionally replicative oncolytic Ads was tested in TC experimental models [94]; however, no further studies were performed.

An adenoviral mutant (dl309) lacking E3 region genes was tested in human K1 cells derived from PTC [95]. High levels of apoptosis were observed correlating to the expression of the viral E1A gene. dl309 virus has not been tested in cells derived from aggressive ATC/PDTC. E3 gene products have a role in preventing innate immunity; however, the efficacy of $d l 309$ to stimulate an immune response against cancer cells was not evaluated.

\subsection{Other OV Effects}

Multiple OVs other than adenoviral mutants have been tested as potential therapeutic agents in preclinical setting of ATC. Oncolytic vaccinia viruses (VACV) derived from vaccinia strains and related to cowpox virus have demonstrated efficacy both in preclinical and clinical studies [96]. Poxviruses used in other types of cancers demonstrated impressive partial and complete responses in a subset of patients. Mundi et al. used a combination of myxoma virus (MYXV) and tanapox virus (TPV), delivered either simultaneously or sequentially. MYXV, a member of Leporipoxviridae is a rabbit-specific poxvirus, its oncolytic potential is favored by the intracellular tumor environment. The oncolysis mechanism of MYXV includes phosphorylation of AKT and loss of synergistic effects of the tumor necrosis factor (TNF) and IFN responses in the neoplastic cells [97,98]. TPV, exhibiting a primate-specific tropism, represents an attractive candidate for oncolytic virotherapy. Its administration to humans induces only mild febrile illness, partially because TPV infection is usually limited to peripheral areas of the body. Indeed, except for endemic areas, person-to-person TPV transmission has not been observed. Overall, VACV showed more efficacy with respect to MYXV and TPV in controlling the viability and inducing death of ATC cells, thus this study confirmed the potential of VACV as a therapeutic agent against ATC/PDTC [99].

GLV-1h68 is a replication-competent VACV bearing mutations in three loci: F14.5L, J2R (encoding for thymidine kinase), and $A 56 R$ (encoding for hemagglutinin). These mutations confer tumor selectivity to the virus and reduce its virulence in normal tissue. This virus also carries marker genes $(r u c-g f p)$ that allow imaging of tumor-specific entry and replication [100]. GLV-1h68 showed significant inhibition of tumor growth after a single administration in ATC cells and tumor xenografts, [101,102]. A variant of GLV-1h68 carrying $h$ NIS symporter gene was produced showing re-expression of $h N I S$ in ATC cells [103]. 
The attenuated vaccine strain of measles virus, MVEdm, has been used in TC models. MVEdm has a specific tropism for CD46 receptor that is highly expressed on cancer cells, including TC [104-106]. Furthermore, to favor TC cell susceptibility to radioiodine therapy, the virus was modified to include the NIS symporter gene (MV-NIS). NIS expression both in vitro and in vivo was confirmed by radioactive iodine uptake along with single-photon emission computed tomography (SPECT) imaging of xenografts. However, ${ }^{131} \mathrm{I}$ administration in MV-NIS-treated animals did not result in a significant enhancement of the effect, further studies on different ATC cells and with different treatment schedules are required [107].

NV1023 is a replication-competent HSV-1 attenuated by a $15 \mathrm{~kb}$ deletion in the inverted repeat region that extends from the $3^{\prime}$ end of UL55 to the promoter for ICP4. This virus was developed from NV1020, a non-selected clonal derivative of R7020, an HSV-1 vector initially designed as an HSV-1/2 vaccine candidate. NV1023 also contains the Escherichia coli $\beta$-galactosidase gene ( $L a C Z)$ that serves as a marker of infection [108-112]. This virus showed cytotoxicity in one papillary, one medullary, and four anaplastic carcinoma cell lines. NV1023 oncolytic activity was confirmed in a xenografts model resulting in significant tumor volume reduction. Interestingly, a single administration of NV1023 in animals injected with papillary carcinoma cells elicited complete tumor resolution, in animals injected with anaplastic carcinoma cell lines significantly decreased the tumor volume however, the benefit of multiple dosing on tumor volume was not apparent [113]. In another study, a significant variation in the ability of NV1023 to enter TC cells was demonstrated evaluating the interaction between HSV-1 envelope glycoprotein $\mathrm{D}(\mathrm{gD})$ with one of three receptors (nectin-1, herpes virus entry mediator (HVEM), 3-O-sulfated heparin sulfate) required for viral entry. The relevance of the receptor Nectin-1 as marker of thyroid cancer sensitivity to herpes oncolytic therapy was validated [114]. In combinatory studies, Lin and colleagues used NV1023 and G207, an attenuated replication competent mutant HSV-1 with paclitaxel and adriamycin. G207 harbors mutations in both copies of the $\gamma 134.5$ gene and a lacZ insertion in UL39 gene that encodes the large subunit of the viral ribonucleotide reductase [108-111]. The combination of G207 with paclitaxel elicited synergy, whereas the association of NV1023 with adriamycin showed antagonistic effects [115].

The herpes OV, G47 $\Delta$ presents the deletion of $\gamma 34.5$ gene that favors tumor cell selective cytotoxicity and virus replication in cells lacking innate immune response. The insertion of lacZ in the UL39 gene inhibits the expression of ICP6, the large subunit of viral ribonucleotide reductase, thus avoiding viral DNA replication in normal cells. Furthermore, the ICP47 deletion enhances MHC class I presentation that activates lymphocytes and reduces NK cytolysis of host cells $[110,116]$. G47 $\Delta$ showed a greater replication capability and a higher anti-tumor activity than G207, indeed elicited significant efficacy against ATC xenografts [116].

The oncolytic activity of Newcastle disease Virus strain FMW (NDV/FMW) has been also documented in ATC using a recombinant NDV carrying the GFP reporter gene. The tumor selectivity of NDV involves defects in anti-viral signaling pathways, in the activation of RAS signaling and the expression of Rac1 protein [117]. A significant and dose-dependent decrease of ATC cell viability was observed along with apoptosis activation. The efficacy of the recombinant virus was confirmed in 3D spheroids and in vivo models [118].

The therapeutic efficacy of BioKnife, an oncolytic recombinant Sendai virus that elicits cytotoxicity dependently on urokinase-type plasminogen activator activity has also been determined. Sendai virus is a natural OV lacking pathogenic effects in humans, but causing respiratory disease in mice. The administration of BioKnife prolonged survival in an orthotopic mouse model (BALB/c nu/nu mice) of ATC following intra-tumor injections [119], this finding also confirms the feasibility of the local treatments.

\subsection{OV Effects in TC Patients}

Clinical trials based on OVs in the treatment of ATC/PDTC have not been performed so far, likely because of the small number of patients and the short survival time. Nevertheless, in a Phase 
II clinical trial investigating the effects of a reovirus (REOLYSIN ${ }^{\circledR}$ ) in combination with low-dose radiation in patients with advanced cancers, a single patient with TC was enrolled and displayed a partial response to the treatment (Intratumoral Administration of REOLYSIN ${ }^{\circledR}$ in Combination with Low-Dose Radiation for Patients with Advanced Malignancies-Trial number REO 008).

Preclinical studies using VB-111, a non-replicating antiangiogenic Ads [120], supported its application in clinical trials. VB-111 is engineered to express Fas-c transgene in endothelial cells and is active only against tumor vasculature. In in vitro studies, infection of HUVEC cells induced massive apoptosis, whereas in animal models reduction of tumor mass and inhibition of metastasis was observed. In a phase I clinical trial, VB-111 proved to be safe and well-tolerated; with fever and chills as side effects. Transgene expression was detected in an aspirate from a subcutaneous metastasis but not in blood after treatment. In this trial, one patient with PTC had a partial response.

In a phase II clinical trial (ClinicalTrials.gov Identifier: NCT01229865, VB-111) in patients with advanced differentiated TC, $44 \%$ of patients experienced tumor regression. VB-111 is devoid of replicative activity, therefore this agent cannot be included among OVs. Overall, data from clinical studies support the use of viruses for the treatments of ATC and PDTC.

\section{Future Treatments Based on OVs}

Although OVs are proving to be effective as anti-cancer therapeutics, their efficacy as single agents is limited and combinations have been tested to enhance their antineoplastic effect.

The combinatorial treatments include the association of OVs with radiotherapy, chemotherapeutic drugs, and novel agents, including immune-checkpoint inhibitors (we refer to the following reviews for a better description of these studies) [121,122].

\subsection{OVs and Chemotherapeutic Drugs}

The combination of OVs with chemotherapeutics is an appealing strategy to increase anti-tumor potency. Different classes of chemotherapeutic agents have been tested in combination with OVs, showing in most cases additive or synergic effects both in preclinical and in clinical models [66]. With the exception of few studies, the mechanism at the base of synergy and increased cell killing was not analyzed.

It is emerging that chemotherapeutic drugs can elicit sub-optimal ICD because they fail to activate crucial DAMPs. In cisplatin-treated tumors although a release of ATP and HMGB1 was observed, the drug failed to induce cell surface CRT exposure [123]. Notably, OVs can induce the expression of broad arrays of DAMPs likely relevant for ICD induction.

Chemotherapeutic drugs (i.e., doxorubicin, paclitaxel) used against ATC have been associated with $d l 1520$, the combinations showed to be more effective with respect to the single agents. In these studies, the capability of the combined treatment to potentiate ICD was not assessed [67]. The effects of 5-FU, gemcitabine, cisplatin, or low dose paclitaxel combined with d1922-947 have been tested in experimental models $[65,77,124]$, but not assessed in ATC cells. The use of OVs with ICD inducers represents an important and promising future research direction, and it could be useful to identify ideal combinations in ATC setting. Moreover, the combination of ICD-inducing agents and OVs (as reported in pf 4.1) can minimize tumor escape variants at the base of treatment resistance.

\subsection{OVs and Immunotherapeutic Agents/Treatments}

Shaping an efficient immune response against tumors likely represents the most innovative therapeutic option available so far. Cancer immunotherapy is a clinically validated treatment for many solid tumors. Immunotherapy includes cancer vaccines, adoptive transfer of activated T or NK cells, the use of chimeric antigen receptor (CAR) T-cells, and blocking antibodies, the so called immune checkpoint inhibitors (ICI, i.e., anti-CTLA4 and anti-PD-1/PD-L1 antibodies) [125]. Immune checkpoint molecules are used by the immune system to maintain homeostasis, these signals are upregulated in tumors to escape the immune responses [126]. ICI are now approved for clinical use [127] and show 
efficacy in lesions with an existing anti-tumor immune response, whereas in tumors with minimal immune cells infiltration are less effective. Evidences suggest the use of ICI in combination with other agents capable of stimulating a robust immune response against neoplastic cells [128].

The analysis of the immunological features of ATC suggests that these tumors can take advantage of the immunotherapeutic option. Recently, transcriptomic and genomic data obtained by Cancer Genome Atlas (TCGA) provided a classification of the cancer stromal compartment including the immune component of solid tumor microenvironment. According to their "immunoscore," tumors were classified into six types [129]. The immunoscore takes into account the tumors antigen burden, the phenotype, and degree of immune cell infiltration, the presence of soluble inhibitory mediators (i.e., TGF-beta, IL-10, VEGF), cell membrane inhibitory receptors (immune checkpoints) or immunosuppressive cells (i.e., myeloid derived suppressor cells, Treg). The TCGA analysis allowed the classification of PTCs as "inflammatory" tumors because of the recognition of an important immune infiltrate [129] despite their well-known low mutational burden. Furthermore, an immune expression profiling of TC confirmed that mostly ATC and PTC show a microenvironment infiltrated by macrophages and $\mathrm{CD} 8^{+} \mathrm{T}$-cells with a functionally exhausted appearance [130]. These reports support the possible classification of the ATC as hot and immunosuppressed tumor and encourage the use of OVs as potential therapeutic option.

Several studies analyzed tumor-infiltrating immune/inflammatory cells in the aggressive forms of TC, and these data supported their role in mounting an anti-tumor response [131,132].

The transcriptomic analysis of TC samples revealed an up-regulation of inhibitory immune checkpoints (PD-1, PD-L1, and PD-L2) [125]. These datas were confirmed by other studies showing that (i) high PD-L1 levels in PTC were correlated with tumor-associated macrophages (TAM) and lymphocytic infiltrate $[133,134]$; (ii) the expression of PD-L1 was significantly associated with increased tumor size and multifocality of PDTC; (iii) PD-1 ${ }^{+}$T-lymphocytes were associated with cancer lymph-nodal invasion and recurrent disease [135].

Moreover, ATC cells express high levels of the enzyme indoleamine 2,3-dioxygenase 1 (IDO1) that catalyzes the conversion of the amino acid tryptophan to the immunosuppressive molecule kynurenines, thus causing halted growth of T cells [136].

The evidence of increased immune checkpoint expression and the existence of an inefficient immune infiltrate points to a promising role of immunotherapy. To date, few case reports presented the results of the effects of ICI in TC patients: pembrolizumab (anti-PD-1) has been used as a neoadjuvant drug allowing the complete surgical resection; in ATC patients, pembrolizumab was also used as salvage therapy added to kinase inhibitors $[137,138]$. More extensively, the utility of ICI in mono- or combination-therapy for advanced forms of TC are under investigation in several "basket clinical trials." These trials are in phase I or II testing pembrolizumab, nivolumab (anti-PD-1), or atezolizumab (anti-PD-L1) alone or in combination with MKIs for advanced and/or metastatic TC (NCT02054806, NCT03246958 II, NCT02501096 and NCT02973997, NCT03181100, NCT01988896) [132].

OVs exert potent immune-stimulatory effects [139] and the lysis of cancer cells induces the release of antigens stimulating the anti-tumor immune response, thus turning "cold" immunosuppressive tumors to "hot" inflamed tumors. Indeed, OVs treatment favors effector T cell recruitment into the TME, and immune checkpoint blockade, via removal of inhibitory signals, and may sustain the potency of tumor infiltrating lymphocytes (TIL), TAM with an inflammatory M1 phenotype and NK cells. Reports strongly support the rationale for the use of OVs and ICI as therapeutic associations to stimulate the immune system against the tumor $[125,140]$. The efficacy of this strategy was confirmed in several studies and in different tumor types. Since the potential immune-stimulatory activity of $d 1922-947$ is known in ATC models, a combination treatment with ICI and d1922-947 could be envisaged.

Another immunotherapeutic option is represented by the adoptive T-cell therapy. This approach has been successful for hematologic malignancies, yielding only modest results in solid tumors. In particular, preclinical results obtained in animal models, pointed at the possibility to consider CAR-T cell therapy targeting intercellular adhesion molecule 1 (ICAM-1) also for advanced human 
TC [141]. The association with OVs augmented the anti-tumor activity of adoptively transferred T-cells $[140,142,143]$ in animal models increasing the survival of treated animals [144]. These studies proved that combining oncolytic virotherapy with adoptive T-cell immunotherapy is possible to control tumor growth.

Bispecific T cell engagers (BiTEs) consist of a CD3-scFv linked to another scFv specific for an antigen expressed on the surface of tumor cells. By utilizing BiTEs, T-cells infiltrating the tumor are re-directed against specific antigens expressed on cancer cells. OVs have been used to express BiTE molecules, providing a retargeting T-cell effect together with the virotherapeutic activity [142].

The development of novel treatments for melanoma can be considered as a paradigm for new anti-neoplastic approaches in different lesions, in particular TC as it shares several genetic lesions with melanoma cells. Bommareddy et al. combined trametinib, a selective MEK inhibitor (MEKi) and T-VEC, in melanoma experimental model observing a significant increase in cytotoxic activity independently of BRAF or NRAS mutation status. The combined treatment was associated with an increase in T-VEC replication. The TME showed an influx of proliferating CD8 ${ }^{+} \mathrm{T}$ cells expressing interferon- $\gamma$ and Granzyme B. Authors observed an upregulation of PD-1 and PD-L1 gene expression in treated mice, suggesting that the therapeutic combination could benefit the PD-1/PD-L1 blockade. The triple combination with T-VEC/MEKi/ $\alpha \mathrm{PD}-1$ was tested in an immune-competent model, showing nearly $80 \%$ of survival [145].

BRAF and RAS mutations represent early mutational events in ATC, and are present in $25 \%$ and $28 \%$ of cases, respectively [6]. BRAF inhibitors, or alternatively inhibitors active on the BRAF-MEK-MAPK signaling cascade, have been already used in ATC patients, and the combination with ICI has been already envisaged in a patient with unresectable ATC. Immunotherapy with pembrolizumab was combined with BRAF inhibitors enabling a complete surgical resection, as already above mentioned [137]. The triple combination MKIs, OVs, and ICI could be explored in ATC models to confirm the efficacy of this approach.

\section{Conclusions}

ATC and PDTC lack of effective therapies and novel treatments are required. Multimodality treatments have not increased the survival rate and the use of MKIs targeting the signaling pathways activated in TC have limited benefits.

OVs are now a clinical reality and have proved efficacy and safety. T-VEC is approved for the treatment of melanoma and its use has been already tested in other lesions in association with immunotherapy or other treatments [146].

The use of OVs for the treatments of ATC-PDTC has been hypothesized already in 2002, however, so far only preclinical studies have been performed in ATC/PDTC models and showed their efficacy against ATC cells and tumor xenografts. Indeed, the clinical administration of OVs in ATC/PDTC patients is limited by the short survival time. The compassionate treatment with OVs of ATC patients in advanced and untreatable stages could be envisaged in order to obtain clinical data and assess the capability of the viruses to stimulate an immune response.

Among the OVs tested in ATC/PDTC experimental models, the adenoviral mutant $d 1922-947$ has been the most studied and its potency demonstrated either as single agent or in combination with other drugs and with IR. dl922-947 modulates the TME activating a robust innate immune response against ATC xenografts. These data confirm this virus as an attractive candidate for clinical studies. dl922-947 has already been evaluated in association with targeted therapeutics (i.e., Aurora B inhibitor) against ATC [82], although more combinations could be envisaged and might prove to be effective. Potentially active associations able to enhance the activity of OVs against TC cells might involve drugs endowed with activity against TC in preclinical and/or clinical studies like tyrosine kinase inhibitors (TKI) targeting multiple molecules or mTOR inhibitors.

Although data indicate that OVs and in particular d $1922-947$ could be beneficial for ATC/PDTC treatment, further studies could be useful to better address and develop therapeutic strategies based on 
OVs. These options of treatment might include the evaluation of OVs armed with immune-stimulatory genes (e.g., IL-12, GM-CSF, IL-2, IL-15, IFN-beta, IFN-gamma, TNF-alpha, CCL5, CCL2, CCL19, CXCL11) or the association with immunotherapeutic agents (e.g., ICI or co-stimulatory ligands) [27]. These combinations already have proved efficacy in other lesions (i.e., advanced melanoma), and could be effective in ATC/PDTC setting.

In conclusion, numerous studies report the efficacy of OVs in the TC preclinical scenario, thus supporting its clinical use in ATC patients in the near future.

Author Contributions: For research articles with several authors, a short paragraph specifying their individual contributions must be provided. The following statements should be used "conceptualization, G.P. and A.M.M; methodology, S.D.S.; software, N.P.; validation, S.D.S. and N.P.; formal analysis, S.D.S.; investigation, N.P.; resources, G.P.; data curation, N.P.; writing—original draft preparation, N.P.; writing-review and editing, A.M.M; visualization, A.M.M.; supervision, G.P.; project administration, A.M.M; funding acquisition, G.P.", please turn to the CRediT taxonomy for the term explanation. Authorship must be limited to those who have contributed substantially to the work reported.

Funding: This work was supported by Programma STAR -Sostegno territoriale alle attività di ricerca - Università degli studi di Napoli Federico II -Linea d'intervento 1 " Oncolytic viral therapy and induction of anti-tumor immune response: a promising approach against malignatnt mesothelioma".

Conflicts of Interest: The authors declare no conflict of interest.

\section{Abbreviations}

APC: antigen presenting cells; ATC, anaplastic thyroid carcinoma; BiTEs, bispecific T cell engagers; CAFs, cancer-associated fibroblasts; CAR-T, chimeric antigen receptor T-cells; CRT, calreticulin; DAMPs, danger associated molecular patterns; DCs, dendritic cells; DDR, DNA damage response; ECHO-7, non-pathogenic enteric cytopathic human orphan type 7; EMT, epithelial-to-mesenchymal transition; FTC, follicular thyroid carcinoma; HSV-1, herpes simplex virus 1; hTert-Ad, human telomerase reverse transcriptase promoter-regulated Ads; ICD, immunogenic cell death; IDO1, indoleamine 2,3-dioxygenase 1; IFNs, interferons; IR, ionizing radiation; MEKi, MEK inhibitor; MKIs, multiple kinase inhibitors; MYXV, oncolytic myxoma virus; NDV/FMW, Newcastle disease Virus NDV strain FMW; NK, natural killer cells; OV, oncolytic viruses; PARP-1, poly (ADP-ribose) polymerase 1; PARP-2, poly (ADP-ribose) polymerase 2; PDTC, poorly differentiated thyroid carcinoma; PKR, protein kinase R; PPE-1, preproendothelin-1; PRRs, pathogen recognition receptors; PTC, papillary thyroid carcinoma; SPECT, single-photon emission computed tomography; TC, thyroid carcinoma; TGF beta-1, transforming growth factor-beta1; TK, tyrosine kinase; TKI, tyrosine kinase inhibitors; TLR, toll-like receptor; TME, tumor microenvironment; T-VEC, talimogene laherparepvec; VEGF, vascular endothelial growth factor.

\section{References}

1. Taccaliti, A.; Silvetti, F.; Palmonella, G.; Boscaro, M. Anaplastic thyroid carcinoma. Front. Endocrinol. 2012, 3, 84. [CrossRef] [PubMed]

2. Hundahl, S.A.; Fleming, I.D.; Fremgen, A.M.; Menck, H.R. A National Cancer Data Base report on 53,856 cases of thyroid carcinoma treated in the U.S., 1985-1995. Cancers 1998, 83, 2638-2648. [CrossRef]

3. Romei, C.; Tacito, A.; Molinaro, E.; Piaggi, P.; Cappagli, V.; Pieruzzi, L.; Matrone, A.; Viola, D.; Agate, L.; Torregrossa, L.; et al. Clinical, pathological and genetic features of anaplastic and poorly differentiated thyroid cancer: A single institute experience. Oncol. Lett. 2018, 15, 9174-9182. [CrossRef] [PubMed]

4. Kitamura, Y.; Shimizu, K.; Nagahama, M.; Sugino, K.; Ozaki, O.; Mimura, T.; Ito, K.; Ito, K.; Tanaka, S. Immediate causes of death in thyroid carcinoma: Clinicopathological analysis of 161 fatal cases. J. Clin. Endocrinol. Metab. 1999, 84, 4043-4049. [CrossRef]

5. Molinaro, E.; Romei, C.; Biagini, A.; Sabini, E.; Agate, L.; Mazzeo, S.; Materazzi, G.; Sellari-Franceschini, S.; Ribechini, A.; Torregrossa, L.; et al. Anaplastic thyroid carcinoma: From clinicopathology to genetics and advanced therapies. Nat. Rev. Endocrinol. 2017, 13, 644-660. [CrossRef]

6. Jaber, T.; Waguespack, S.G.; Cabanillas, M.E.; Elbanan, M.; Vu, T.; Dadu, R.; Sherman, S.I.; Amit, M.; Santos, E.B.; Zafereo, M.; et al. Targeted Therapy in Advanced Thyroid Cancer to Resensitize Tumors to Radioactive Iodine. J. Clin. Endocrinol. Metab. 2018, 103, 3698-3705. [CrossRef]

7. Tahara, M. Management of recurrent or metastatic thyroid cancer. ESMO Open 2018, 3, e000359. [CrossRef]

8. Russell, S.J.; Peng, K.W.; Bell, J.C. Oncolytic virotherapy. Nat. Biotechnol. 2012, 30, 658-670. [CrossRef]

9. Lichty, B.D.; Breitbach, C.J.; Stojdl, D.F.; Bell, J.C. Going viral with cancer immunotherapy. Nat. Rev. Cancer 2014, 14, 559-567. [CrossRef] 
10. Kelly, E.; Russell, S.J. History of oncolytic viruses: Genesis to genetic engineering. Mol. Ther. 2007, 15, 651-659. [CrossRef]

11. Bierman, H.R.; Crile, D.M.; Dod, K.S.; Kelly, K.H.; Petrakis, N.L.; White, L.P.; Shimkin, M.B. Remissions in leukemia of childhood following acute infectious disease: Staphylococcus and streptococcus, varicella, and feline panleukopenia. Cancer 1953, 6, 591-605. [CrossRef]

12. Martuza, R.L.; Malick, A.; Markert, J.M.; Ruffner, K.L.; Coen, D.M. Experimental therapy of human glioma by means of a genetically engineered virus mutant. Science 1991, 252, 854-856. [CrossRef] [PubMed]

13. Parato, K.A.; Senger, D.; Forsyth, P.A.; Bell, J.C. Recent progress in the battle between oncolytic viruses and tumours. Nat. Rev. Cancer 2005, 5, 965-976. [CrossRef] [PubMed]

14. O'Shea, C.C.; Johnson, L.; Bagus, B.; Choi, S.; Nicholas, C.; Shen, A.; Boyle, L.; Pandey, K.; Soria, C.; Kunich, J.; et al. Late viral RNA export, rather than p53 inactivation, determines ONYX-015 tumor selectivity. Cancer Cell 2004, 6, 611-623. [CrossRef]

15. Liu, T.C.; Galanis, E.; Kirn, D. Clinical trial results with oncolytic virotherapy: A century of promise, a decade of progress. Nat. Clin. Prog. Oncol. 2007, 4, 101-117. [CrossRef]

16. Larson, C.; Oronsky, B.; Scicinski, J.; Fanger, G.R.; Stirn, M.; Oronsky, A.; Reid, T.R. Going viral: A review of replication-selective oncolytic adenoviruses. Oncotarget 2015, 6, 19976-19989. [CrossRef]

17. Maroun, J.; Munoz-Alia, M.; Ammayappan, A.; Schulze, A.; Peng, K.W.; Russell, S. Designing and building oncolytic viruses. Future Virol. 2017, 12, 193-213. [CrossRef]

18. Babiker, H.M.; Riaz, I.B.; Husnain, M.; Borad, M.J. Oncolytic virotherapy including Rigvir and standard therapies in malignant melanoma. Oncolytic Virother. 2017, 6, 11-18. [CrossRef]

19. Alberts, P.; Olmane, E.; Brokane, L.; Krastina, Z.; Romanovska, M.; Kupcs, K.; Isajevs, S.; Proboka, G.; Erdmanis, R.; Nazarovs, J.; et al. Long-term treatment with the oncolytic ECHO-7 virus Rigvir of a melanoma stage IV M1c patient, a small cell lung cancer stage IIIA patient, and a histiocytic sarcoma stage IV patient-three case reports. APMIS 2016, 124, 896-904. [CrossRef]

20. Alberts, P.; Tilgase, A.; Rasa, A.; Bandere, K.; Venskus, D. The advent of oncolytic virotherapy in oncology: The Rigvir(R) story. Eur. J. Pharm. 2018, 837, 117-126. [CrossRef]

21. Garber, K. China approves world's first oncolytic virus therapy for cancer treatment. J. Natl. Cancer Inst. 2006, 98, 298-300. [CrossRef] [PubMed]

22. Xia, Z.J.; Chang, J.H.; Zhang, L.; Jiang, W.Q.; Guan, Z.Z.; Liu, J.W.; Zhang, Y.; Hu, X.H.; Wu, G.H.; Wang, H.Q.; et al. Phase III randomized clinical trial of intratumoral injection of E1B gene-deleted adenovirus (H101) combined with cisplatin-based chemotherapy in treating squamous cell cancer of head and neck or esophagus. Ai Zheng 2004, 23, 1666-1670. [PubMed]

23. Andtbacka, R.H.; Kaufman, H.L.; Collichio, F.; Amatruda, T.; Senzer, N.; Chesney, J.; Delman, K.A.; Spitler, L.E.; Puzanov, I.; Agarwala, S.S.; et al. Talimogene Laherparepvec Improves Durable Response Rate in Patients with Advanced Melanoma. J. Clin. Oncol. 2015, 33, 2780-2788. [CrossRef] [PubMed]

24. Conry, R.M.; Westbrook, B.; McKee, S.; Norwood, T.G. Talimogene laherparepvec: First in class oncolytic virotherapy. Hum. Vaccines Immunother. 2018, 14, 839-846. [CrossRef] [PubMed]

25. Jhawar, S.R.; Thandoni, A.; Bommareddy, P.K.; Hassan, S.; Kohlhapp, F.J.; Goyal, S.; Schenkel, J.M.; Silk, A.W.; Zloza, A. Oncolytic Viruses-Natural and Genetically Engineered Cancer Immunotherapies. Front. Oncol. 2017, 7, 202. [CrossRef] [PubMed]

26. Lawler, S.E.; Speranza, M.C.; Cho, C.F.; Chiocca, E.A. Oncolytic Viruses in Cancer Treatment: A Review. JAMA Oncol. 2017, 3, 841-849. [CrossRef]

27. De Graaf, J.F.; de Vor, L.; Fouchier, R.A.M.; van den Hoogen, B.G. Armed oncolytic viruses: A kick-start for anti-tumor immunity. Cytokine Growth Factor Rev. 2018, 41, 28-39. [CrossRef]

28. Raftery, N.; Stevenson, N.J. Advances in anti-viral immune defence: Revealing the importance of the IFN JAK/STAT pathway. Cell Mol. Life Sci. 2017, 74, 2525-2535. [CrossRef]

29. Kaufman, H.L.; Kohlhapp, F.J.; Zloza, A. Oncolytic viruses: A new class of immunotherapy drugs. Nat. Rev. Drug Discov. 2015, 14, 642-662. [CrossRef]

30. Budczies, J.; Bockmayr, M.; Klauschen, F.; Endris, V.; Frohling, S.; Schirmacher, P.; Denkert, C.; Stenzinger, A. Mutation patterns in genes encoding interferon signaling and antigen presentation: A pan-cancer survey with implications for the use of immune checkpoint inhibitors. Genes Chromosom. Cancer 2017, 56, 651-659. [CrossRef] 
31. Xia, T.; Konno, H.; Ahn, J.; Barber, G.N. Deregulation of STING Signaling in Colorectal Carcinoma Constrains DNA Damage Responses and Correlates with Tumorigenesis. Cell Rep. 2016, 14, 282-297. [CrossRef] [PubMed]

32. Linsley, P.S.; Speake, C.; Whalen, E.; Chaussabel, D. Copy number loss of the interferon gene cluster in melanomas is linked to reduced $\mathrm{T}$ cell infiltrate and poor patient prognosis. PLoS ONE 2014, 9, e109760. [CrossRef] [PubMed]

33. Crupi, M.J.F.; Bell, J.C.; Singaravelu, R. Concise Review: Targeting Cancer Stem Cells and Their Supporting Niche Using Oncolytic Viruses. Stem Cells 2019, 37, 716-723. [CrossRef] [PubMed]

34. Dalet, A.; Gatti, E.; Pierre, P. Integration of PKR-dependent translation inhibition with innate immunity is required for a coordinated anti-viral response. FEBS Lett. 2015, 589, 1539-1545. [CrossRef]

35. Williams, B.R. PKR; a sentinel kinase for cellular stress. Oncogene 1999, 18, 6112-6120. [CrossRef]

36. Dauber, B.; Wolff, T. Activation of the Antiviral Kinase PKR and Viral Countermeasures. Viruses 2009, 1, 523-544. [CrossRef]

37. Farassati, F.; Yang, A.D.; Lee, P.W. Oncogenes in Ras signalling pathway dictate host-cell permissiveness to herpes simplex virus 1. Nat. Cell Biol. 2001, 3, 745-750. [CrossRef]

38. Smith, K.D.; Mezhir, J.J.; Bickenbach, K.; Veerapong, J.; Charron, J.; Posner, M.C.; Roizman, B.; Weichselbaum, R.R. Activated MEK suppresses activation of PKR and enables efficient replication and in vivo oncolysis by Deltagamma(1)34.5 mutants of herpes simplex virus 1. J. Virol. 2006, 80, 1110-1120. [CrossRef]

39. Terada, T.; Maeta, H.; Endo, K.; Ohta, T. Protein expression of double-stranded RNA-activated protein kinase in thyroid carcinomas: Correlations with histologic types, pathologic parameters, and Ki-67 labeling. Hum. Pathol. 2000, 31, 817-821. [CrossRef]

40. Harrington, K.; Freeman, D.J.; Kelly, B.; Harper, J.; Soria, J.C. Optimizing oncolytic virotherapy in cancer treatment. Nat. Rev. Drug Discov. 2019, 18, 689-706. [CrossRef]

41. Bartlett, D.L.; Liu, Z.; Sathaiah, M.; Ravindranathan, R.; Guo, Z.; He, Y.; Guo, Z.S. Oncolytic viruses as therapeutic cancer vaccines. Mol. Cancer 2013, 12, 103. [CrossRef] [PubMed]

42. Inoue, H.; Tani, K. Multimodal immunogenic cancer cell death as a consequence of anticancer cytotoxic treatments. Cell Death Differ. 2014, 21, 39-49. [CrossRef] [PubMed]

43. Galluzzi, L.; Vitale, I.; Aaronson, S.A.; Abrams, J.M.; Adam, D.; Agostinis, P.; Alnemri, E.S.; Altucci, L.; Amelio, I.; Andrews, D.W.; et al. Molecular mechanisms of cell death: Recommendations of the Nomenclature Committee on Cell Death 2018. Cell Death Differ. 2018, 25, 486-541. [PubMed]

44. Obeid, M.; Tesniere, A.; Ghiringhelli, F.; Fimia, G.M.; Apetoh, L.; Perfettini, J.L.; Castedo, M.; Mignot, G.; Panaretakis, T.; Casares, N.; et al. Calreticulin exposure dictates the immunogenicity of cancer cell death. Nat. Med. 2007, 13, 54-61. [CrossRef] [PubMed]

45. Obeid, M.; Tesniere, A.; Panaretakis, T.; Tufi, R.; Joza, N.; van Endert, P.; Ghiringhelli, F.; Apetoh, L.; Chaput, N.; Flament, C.; et al. Ecto-calreticulin in immunogenic chemotherapy. Immunol. Rev. 2007, 220, 22-34. [CrossRef] [PubMed]

46. Yanai, H.; Ban, T.; Taniguchi, T. High-mobility group box family of proteins: Ligand and sensor for innate immunity. Trends Immunol. 2012, 33, 633-640. [CrossRef] [PubMed]

47. Garg, A.D.; Galluzzi, L.; Apetoh, L.; Baert, T.; Birge, R.B.; Bravo-San Pedro, J.M.; Breckpot, K.; Brough, D.; Chaurio, R.; Cirone, M.; et al. Molecular and Translational Classifications of DAMPs in Immunogenic Cell Death. Front. Immunol. 2015, 6, 588. [CrossRef]

48. Bommareddy, P.K.; Shettigar, M.; Kaufman, H.L. Integrating oncolytic viruses in combination cancer immunotherapy. Nat. Rev. Immunol. 2018, 18, 498-513. [CrossRef]

49. Van Vloten, J.P.; Workenhe, S.T.; Wootton, S.K.; Mossman, K.L.; Bridle, B.W. Critical Interactions between Immunogenic Cancer Cell Death, Oncolytic Viruses, and the Immune System Define the Rational Design of Combination Immunotherapies. J. Immunol. 2018, 200, 450-458. [CrossRef] [PubMed]

50. Ye, T.; Jiang, K.; Wei, L.; Barr, M.P.; Xu, Q.; Zhang, G.; Ding, C.; Meng, S.; Piao, H. Oncolytic Newcastle disease virus induces autophagy-dependent immunogenic cell death in lung cancer cells. Am. J. Cancer Res. 2018, 8, 1514-1527.

51. Annels, N.E.; Arif, M.; Simpson, G.R.; Denyer, M.; Moller-Levet, C.; Mansfield, D.; Butler, R.; Shafren, D.; $\mathrm{Au}, \mathrm{G}$; Knowles, M.; et al. Oncolytic Immunotherapy for Bladder Cancer Using Coxsackie A21 Virus. Mol. Ther. Oncolytics 2018, 9, 1-12. [CrossRef] 
52. Diaconu, I.; Cerullo, V.; Hirvinen, M.L.; Escutenaire, S.; Ugolini, M.; Pesonen, S.K.; Bramante, S.; Parviainen, S.; Kanerva, A.; Loskog, A.S.; et al. Immune response is an important aspect of the antitumor effect produced by a CD40L-encoding oncolytic adenovirus. Cancer Res. 2012, 72, 2327-2338. [CrossRef] [PubMed]

53. Donnelly, O.G.; Errington-Mais, F.; Steele, L.; Hadac, E.; Jennings, V.; Scott, K.; Peach, H.; Phillips, R.M.; Bond, J.; Pandha, H.; et al. Measles virus causes immunogenic cell death in human melanoma. Gene Ther. 2013, 20, 7-15. [CrossRef]

54. Kelly, K.R.; Espitia, C.M.; Mahalingam, D.; Oyajobi, B.O.; Coffey, M.; Giles, F.J.; Carew, J.S.; Nawrocki, S.T. Reovirus therapy stimulates endoplasmic reticular stress, NOXA induction, and augments bortezomib-mediated apoptosis in multiple myeloma. Oncogene 2012, 31, 3023-3038. [CrossRef] [PubMed]

55. Miyamoto, S.; Inoue, H.; Nakamura, T.; Yamada, M.; Sakamoto, C.; Urata, Y.; Okazaki, T.; Marumoto, T.; Takahashi, A.; Takayama, K.; et al. Coxsackievirus B3 is an oncolytic virus with immunostimulatory properties that is active against lung adenocarcinoma. Cancer Res. 2012, 72, 2609-2621. [CrossRef]

56. Workenhe, S.T.; Mossman, K.L. Oncolytic virotherapy and immunogenic cancer cell death: Sharpening the sword for improved cancer treatment strategies. Mol. Ther. 2014, 22, 251-256. [CrossRef] [PubMed]

57. Boozari, B.; Mundt, B.; Woller, N.; Struver, N.; Gurlevik, E.; Schache, P.; Kloos, A.; Knocke, S.; Manns, M.P.; Wirth, T.C.; et al. Antitumoural immunity by virus-mediated immunogenic apoptosis inhibits metastatic growth of hepatocellular carcinoma. Gut 2010, 59, 1416-1426. [CrossRef]

58. Workenhe, S.T.; Simmons, G.; Pol, J.G.; Lichty, B.D.; Halford, W.P.; Mossman, K.L. Immunogenic HSV-mediated oncolysis shapes the antitumor immune response and contributes to therapeutic efficacy. Mol. Ther. 2014, 22, 123-131. [CrossRef] [PubMed]

59. Liikanen, I.; Ahtiainen, L.; Hirvinen, M.L.; Bramante, S.; Cerullo, V.; Nokisalmi, P.; Hemminki, O.; Diaconu, I.; Pesonen, S.; Koski, A.; et al. Oncolytic adenovirus with temozolomide induces autophagy and antitumor immune responses in cancer patients. Mol. Ther. 2013, 21, 1212-1223. [CrossRef]

60. Pothula, S.P.; Xu, Z.; Goldstein, D.; Merrett, N.; Pirola, R.C.; Wilson, J.S.; Apte, M.V. Targeting the HGF/c-MET pathway: Stromal remodelling in pancreatic cancer. Oncotarget 2017, 8, 76722-76739. [CrossRef]

61. Su, S.; Chen, J.; Yao, H.; Liu, J.; Yu, S.; Lao, L.; Wang, M.; Luo, M.; Xing, Y.; Chen, F.; et al. CD10(+)GPR77(+) Cancer-Associated Fibroblasts Promote Cancer Formation and Chemoresistance by Sustaining Cancer Stemness. Cell 2018, 172, 841-856 e16. [CrossRef] [PubMed]

62. Ilkow, C.S.; Marguerie, M.; Batenchuk, C.; Mayer, J.; Ben Neriah, D.; Cousineau, S.; Falls, T.; Jennings, V.A.; Boileau, M.; Bellamy, D.; et al. Reciprocal cellular cross-talk within the tumor microenvironment promotes oncolytic virus activity. Nat. Med. 2015, 21, 530-536. [CrossRef] [PubMed]

63. Arulanandam, R.; Batenchuk, C.; Angarita, F.A.; Ottolino-Perry, K.; Cousineau, S.; Mottashed, A.; Burgess, E.; Falls, T.J.; De Silva, N.; Tsang, J.; et al. VEGF-Mediated Induction of PRD1-BF1/Blimp1 Expression Sensitizes Tumor Vasculature to Oncolytic Virus Infection. Cancer Cell 2015, 28, 210-224. [CrossRef] [PubMed]

64. Breitbach, C.J.; Arulanandam, R.; De Silva, N.; Thorne, S.H.; Patt, R.; Daneshmand, M.; Moon, A.; Ilkow, C.; Burke, J.; Hwang, T.H.; et al. Oncolytic vaccinia virus disrupts tumor-associated vasculature in humans. Cancer Res. 2013, 73, 1265-1275. [CrossRef]

65. Passaro, C.; Borriello, F.; Vastolo, V.; Di Somma, S.; Scamardella, E.; Gigantino, V.; Franco, R.; Marone, G.; Portella, G. The oncolytic virus d1922-947 reduces IL-8/CXCL8 and MCP-1/CCL2 expression and impairs angiogenesis and macrophage infiltration in anaplastic thyroid carcinoma. Oncotarget 2016, 7, 1500-1515. [CrossRef]

66. Bressy, C.; Benihoud, K. Association of oncolytic adenoviruses with chemotherapies: An overview and future directions. Biochem. Pharm. 2014, 90, 97-106. [CrossRef]

67. Portella, G.; Scala, S.; Vitagliano, D.; Vecchio, G.; Fusco, A. ONYX-015, an E1B gene-defective adenovirus, induces cell death in human anaplastic thyroid carcinoma cell lines. J. Clin. Endocrinol. Metab. 2002, 87, 2525-2531. [CrossRef]

68. Portella, G.; Pacelli, R.; Libertini, S.; Cella, L.; Vecchio, G.; Salvatore, M.; Fusco, A. ONYX-015 enhances radiation-induced death of human anaplastic thyroid carcinoma cells. J. Clin. Endocrinol. Metab. 2003, 88, 5027-5032. [CrossRef]

69. Bifulco, M. Therapeutic potential of statins in thyroid proliferative disease. Nat. Clin. Prog. Endocrinol. Metab. 2008, 4, 242-243. [CrossRef] 
70. Wang, C.Y.; Zhong, W.B.; Chang, T.C.; Lai, S.M.; Tsai, Y.F. Lovastatin, a 3-hydroxy-3-methylglutaryl coenzyme A reductase inhibitor, induces apoptosis and differentiation in human anaplastic thyroid carcinoma cells. J. Clin. Endocrinol. Metab. 2003, 88, 3021-3026. [CrossRef]

71. Marlow, L.A.; D'Innocenzi, J.; Zhang, Y.; Rohl, S.D.; Cooper, S.J.; Sebo, T.; Grant, C.; McIver, B.; Kasperbauer, J.L.; Wadsworth, J.T.; et al. Detailed molecular fingerprinting of four new anaplastic thyroid carcinoma cell lines and their use for verification of RhoB as a molecular therapeutic target. J. Clin. Endocrinol. Metab. 2010, 95, 5338-5347. [CrossRef] [PubMed]

72. Libertini, S.; Iacuzzo, I.; Ferraro, A.; Vitale, M.; Bifulco, M.; Fusco, A.; Portella, G. Lovastatin enhances the replication of the oncolytic adenovirus $\mathrm{d} 11520$ and its antineoplastic activity against anaplastic thyroid carcinoma cells. Endocrinology 2007, 148, 5186-5194. [CrossRef] [PubMed]

73. Libertini, S.; Iacuzzo, I.; Perruolo, G.; Scala, S.; Ierano, C.; Franco, R.; Hallden, G.; Portella, G. Bevacizumab increases viral distribution in human anaplastic thyroid carcinoma xenografts and enhances the effects of E1A-defective adenovirus d1922-947. Clin. Cancer Res. 2008, 14, 6505-6514. [CrossRef] [PubMed]

74. Guan, M.; Romano, G.; Coroniti, R.; Henderson, E.E. Progress in oncolytic virotherapy for the treatment of thyroid malignant neoplasm. J. Exp. Clin. Cancer Res. 2014, 33, 91. [PubMed]

75. Heise, C.; Hermiston, T.; Johnson, L.; Brooks, G.; Sampson-Johannes, A.; Williams, A.; Hawkins, L.; Kirn, D. An adenovirus E1A mutant that demonstrates potent and selective systemic anti-tumoral efficacy. Nat. Med. 2000, 6, 1134-1139. [CrossRef]

76. Sherr, C.J.; McCormick, F. The RB and p53 pathways in cancer. Cancer Cell 2002, 2, 103-112. [CrossRef]

77. Bhattacharyya, M.; Francis, J.; Eddouadi, A.; Lemoine, N.R.; Hallden, G. An oncolytic adenovirus defective in pRb-binding (d1922-947) can efficiently eliminate pancreatic cancer cells and tumors in vivo in combination with 5-FU or gemcitabine. Cancer Gene Ther. 2011, 18, 734-743. [CrossRef]

78. Cherubini, G.; Kallin, C.; Mozetic, A.; Hammaren-Busch, K.; Muller, H.; Lemoine, N.R.; Hallden, G. The oncolytic adenovirus AdDeltaDelta enhances selective cancer cell killing in combination with DNA-damaging drugs in pancreatic cancer models. Gene Ther. 2011, 18, 1157-1165. [CrossRef]

79. Botta, G.; Passaro, C.; Libertini, S.; Abagnale, A.; Barbato, S.; Maione, A.S.; Hallden, G.; Beguinot, F.; Formisano, P.; Portella, G. Inhibition of autophagy enhances the effects of E1A-defective oncolytic adenovirus d1922-947 against glioma cells in vitro and in vivo. Hum. Gene Ther. 2012, 23, 623-634. [CrossRef]

80. Oberg, D.; Yanover, E.; Adam, V.; Sweeney, K.; Costas, C.; Lemoine, N.R.; Hallden, G. Improved potency and selectivity of an oncolytic E1ACR2 and E1B19K deleted adenoviral mutant in prostate and pancreatic cancers. Clin. Cancer Res. 2010, 16, 541-553. [CrossRef]

81. Lockley, M.; Fernandez, M.; Wang, Y.; Li, N.F.; Conroy, S.; Lemoine, N.; McNeish, I. Activity of the adenoviral E1A deletion mutant d1922-947 in ovarian cancer: Comparison with E1A wild-type viruses, bioluminescence monitoring, and intraperitoneal delivery in icodextrin. Cancer Res. 2006, 66, 989-998. [CrossRef] [PubMed]

82. Libertini, S.; Abagnale, A.; Passaro, C.; Botta, G.; Barbato, S.; Chieffi, P.; Portella, G. AZD1152 negatively affects the growth of anaplastic thyroid carcinoma cells and enhances the effects of oncolytic virus d1922-947. Endocr. Relat. Cancer 2011, 18, 129-141. [CrossRef] [PubMed]

83. Passaro, C.; Abagnale, A.; Libertini, S.; Volpe, M.; Botta, G.; Cella, L.; Pacelli, R.; Hallden, G.; Gillespie, D.; Portella, G. Ionizing radiation enhances d1922-947-mediated cell death of anaplastic thyroid carcinoma cells. Endocr. Relat. Cancer 2013, 20, 633-647. [CrossRef] [PubMed]

84. Passaro, C.; Volpe, M.; Botta, G.; Scamardella, E.; Perruolo, G.; Gillespie, D.; Libertini, S.; Portella, G. PARP inhibitor olaparib increases the oncolytic activity of d1922-947 in in vitro and in vivo model of anaplastic thyroid carcinoma. Mol. Oncol. 2015, 9, 78-92. [CrossRef]

85. Vaha-Koskela, M.; Hinkkanen, A. Tumor Restrictions to Oncolytic Virus. Biomedicines 2014, 2, $163-194$. [CrossRef]

86. Salnikov, A.V.; Heldin, N.E.; Stuhr, L.B.; Wiig, H.; Gerber, H.; Reed, R.K.; Rubin, K. Inhibition of carcinoma cell-derived VEGF reduces inflammatory characteristics in xenograft carcinoma. Int. J. Cancer 2006, 119, 2795-2802. [CrossRef]

87. Sorrentino, R.; Libertini, S.; Pallante, P.L.; Troncone, G.; Palombini, L.; Bavetsias, V.; Spalletti-Cernia, D.; Laccetti, P.; Linardopoulos, S.; Chieffi, P.; et al. Aurora B overexpression associates with the thyroid carcinoma undifferentiated phenotype and is required for thyroid carcinoma cell proliferation. J. Clin. Endocrinol. Metab. 2005, 90, 928-935. [CrossRef] 
88. Lilley, C.E.; Schwartz, R.A.; Weitzman, M.D. Using or abusing: Viruses and the cellular DNA damage response. Trends Microbiol. 2007, 15, 119-126. [CrossRef]

89. Nichols, G.J.; Schaack, J.; Ornelles, D.A. Widespread phosphorylation of histone H2AX by species C adenovirus infection requires viral DNA replication. J. Virol. 2009, 83, 5987-5998. [CrossRef]

90. Touchefeu, Y.; Vassaux, G.; Harrington, K.J. Oncolytic viruses in radiation oncology. Radiother. Oncol. 2011, 99, 262-270. [CrossRef] [PubMed]

91. Ame, J.C.; Spenlehauer, C.; de Murcia, G. The PARP superfamily. Bioessays 2004, 26, 882-893. [CrossRef] [PubMed]

92. McCabe, N.; Turner, N.C.; Lord, C.J.; Kluzek, K.; Bialkowska, A.; Swift, S.; Giavara, S.; O'Connor, M.J.; Tutt, A.N.; Zdzienicka, M.Z.; et al. Deficiency in the repair of DNA damage by homologous recombination and sensitivity to poly(ADP-ribose) polymerase inhibition. Cancer Res. 2006, 66, 8109-8115. [CrossRef] [PubMed]

93. Abbosh, P.H.; Li, X.; Li, L.; Gardner, T.A.; Kao, C.; Nephew, K.P. A conditionally replicative, Wnt/beta-catenin pathway-based adenovirus therapy for anaplastic thyroid cancer. Cancer Gene Ther. 2007, 14, 399-408. [CrossRef] [PubMed]

94. Reddi, H.V.; Madde, P.; Reichert-Eberhardt, A.J.; Galanis, E.C.; Copland, J.A.; McIver, B.; Grebe, S.K.; Eberhardt, N.L. ONYX-411, a conditionally replicative oncolytic adenovirus, induces cell death in anaplastic thyroid carcinoma cell lines and suppresses the growth of xenograft tumors in nude mice. Cancer Gene Ther. 2008, 15, 750-757. [CrossRef]

95. Hibma, M.H.; Real, N.C.; Wiles, A.; Dobson-Le, D.; Dix, B.R.; Wynford-Thomas, D.; Braithwaite, A.W.; Royds, J.A. Increased apoptosis and reduced replication efficiency of the E3 region-modified dl309 adenovirus in cancer cells. Virus Res. 2009, 145, 112-120. [CrossRef]

96. Russell, L.; Peng, K.W. The emerging role of oncolytic virus therapy against cancer. Chin. Clin. Oncol. 2018, 7, 16. [CrossRef]

97. Nounamo, B.; Liem, J.; Cannon, M.; Liu, J. Myxoma Virus Optimizes Cisplatin for the Treatment of Ovarian Cancer In Vitro and in a Syngeneic Murine Dissemination Model. Mol. Ther. Oncolytics 2017, 6, 90-99. [CrossRef]

98. Wang, G.; Barrett, J.W.; Stanford, M.; Werden, S.J.; Johnston, J.B.; Gao, X.; Sun, M.; Cheng, J.Q.; McFadden, G. Infection of human cancer cells with myxoma virus requires Akt activation via interaction with a viral ankyrin-repeat host range factor. Proc. Natl. Acad. Sci. USA 2006, 103, 4640-4645. [CrossRef]

99. Mundi, N.; Um, S.; Yoo, J.; Rizzo, G.; Black, M.; Pinto, N.; Palma, D.A.; Fung, K.; MacNeil, D.; Mymryk, J.S.; et al. The control of anaplastic thyroid carcinoma cell lines by oncolytic poxviruses. Virus Res. 2014, 190, 53-59. [CrossRef]

100. Zhang, Q.; Yu, Y.A.; Wang, E.; Chen, N.; Danner, R.L.; Munson, P.J.; Marincola, F.M.; Szalay, A.A. Eradication of solid human breast tumors in nude mice with an intravenously injected light-emitting oncolytic vaccinia virus. Cancer Res. 2007, 67, 10038-10046. [CrossRef]

101. Lin, S.F.; Yu, Z.; Riedl, C.; Woo, Y.; Zhang, Q.; Yu, Y.A.; Timiryasova, T.; Chen, N.; Shah, J.P.; Szalay, A.A.; et al. Treatment of anaplastic thyroid carcinoma in vitro with a mutant vaccinia virus. Surgery 2007, 142, 976-983. [CrossRef] [PubMed]

102. Lin, S.F.; Price, D.L.; Chen, C.H.; Brader, P.; Li, S.; Gonzalez, L.; Zhang, Q.; Yu, Y.A.; Chen, N.; Szalay, A.A.; et al. Oncolytic vaccinia virotherapy of anaplastic thyroid cancer in vivo. J. Clin. Endocrinol. Metab. 2008, 93, 4403-4407. [CrossRef] [PubMed]

103. Gholami, S.; Haddad, D.; Chen, C.H.; Chen, N.G.; Zhang, Q.; Zanzonico, P.B.; Szalay, A.A.; Fong, Y. Novel therapy for anaplastic thyroid carcinoma cells using an oncolytic vaccinia virus carrying the human sodium iodide symporter. Surgery 2011, 150, 1040-1047. [CrossRef] [PubMed]

104. Rota, J.S.; Wang, Z.D.; Rota, P.A.; Bellini, W.J. Comparison of sequences of the H, F, and N coding genes of measles virus vaccine strains. Virus Res. 1994, 31, 317-330. [CrossRef]

105. Yamakawa, M.; Yamada, K.; Tsuge, T.; Ohrui, H.; Ogata, T.; Dobashi, M.; Imai, Y. Protection of thyroid cancer cells by complement-regulatory factors. Cancer 1994, 73, 2808-2817. [CrossRef]

106. Anderson, B.D.; Nakamura, T.; Russell, S.J.; Peng, K.W. High CD46 receptor density determines preferential killing of tumor cells by oncolytic measles virus. Cancer Res. 2004, 64, 4919-4926. [CrossRef] 
107. Reddi, H.V.; Madde, P.; McDonough, S.J.; Trujillo, M.A.; Morris, J.C., 3rd; Myers, R.M.; Peng, K.W.; Russell, S.J.; McIver, B.; Eberhardt, N.L. Preclinical efficacy of the oncolytic measles virus expressing the sodium iodide symporter in iodine non-avid anaplastic thyroid cancer: A novel therapeutic agent allowing noninvasive imaging and radioiodine therapy. Cancer Gene Ther. 2012, 19, 659-665. [CrossRef]

108. Advani, S.J.; Chung, S.M.; Yan, S.Y.; Gillespie, G.Y.; Markert, J.M.; Whitley, R.J.; Roizman, B.; Weichselbaum, R.R. Replication-competent, nonneuroinvasive genetically engineered herpes virus is highly effective in the treatment of therapy-resistant experimental human tumors. Cancer Res. 1999, 59, 2055-2058.

109. Todo, T. Oncolytic virus therapy using genetically engineered herpes simplex viruses. Front. Biosci. 2008, 13, 2060-2064. [CrossRef] [PubMed]

110. Varghese, S.; Rabkin, S.D. Oncolytic herpes simplex virus vectors for cancer virotherapy. Cancer Gene Ther. 2002, 9, 967-978. [CrossRef]

111. Goldstein, D.J.; Weller, S.K. Factor(s) present in herpes simplex virus type 1-infected cells can compensate for the loss of the large subunit of the viral ribonucleotide reductase: Characterization of an ICP6 deletion mutant. Virology 1988, 166, 41-51. [CrossRef]

112. Liu, R.; Varghese, S.; Rabkin, S.D. Oncolytic herpes simplex virus vector therapy of breast cancer in C3(1)/SV40 T-antigen transgenic mice. Cancer Res. 2005, 65, 1532-1540. [CrossRef] [PubMed]

113. Yu, Z.; Eisenberg, D.P.; Singh, B.; Shah, J.P.; Fong, Y.; Wong, R.J. Treatment of aggressive thyroid cancer with an oncolytic herpes virus. Int. J. Cancer 2004, 112, 525-532. [CrossRef] [PubMed]

114. Huang, Y.Y.; Yu, Z.; Lin, S.F.; Li, S.; Fong, Y.; Wong, R.J. Nectin-1 is a marker of thyroid cancer sensitivity to herpes oncolytic therapy. J. Clin. Endocrinol. Metab. 2007, 92, 1965-1970. [CrossRef]

115. Lin, S.F.; Gao, S.P.; Price, D.L.; Li, S.; Chou, T.C.; Singh, P.; Huang, Y.Y.; Fong, Y.; Wong, R.J. Synergy of a herpes oncolytic virus and paclitaxel for anaplastic thyroid cancer. Clin. Cancer Res. 2008, 14, 1519-1528. [CrossRef]

116. Wang, J.N.; Xu, L.H.; Zeng, W.G.; Hu, P.; Rabkin, S.D.; Liu, R.R. Treatment of human thyroid carcinoma cells with the g47delta oncolytic herpes simplex virus. Asian Pac. J. Cancer Prev. 2015, 16, 1241-1245. [CrossRef]

117. Schirrmacher, V. Fifty Years of Clinical Application of Newcastle Disease Virus: Time to Celebrate! Biomedicines 2016, 4, 16. [CrossRef]

118. Jiang, K.; Song, C.; Kong, L.; Hu, L.; Lin, G.; Ye, T.; Yao, G.; Wang, Y.; Chen, H.; Cheng, W.; et al. Recombinant oncolytic Newcastle disease virus displays antitumor activities in anaplastic thyroid cancer cells. BMC Cancer 2018, 18, 746. [CrossRef] [PubMed]

119. Miyagawa, Y.; Araki, K.; Yamashita, T.; Tanaka, S.; Tanaka, Y.; Tomifuji, M.; Ueda, Y.; Yonemitsu, Y.; Shimada, H.; Shiotani, A. Induction of cell fusion/apoptosis in anaplastic thyroid carcinoma in orthotopic mouse model by urokinase-specific oncolytic Sendai virus. Head Neck 2019, 41, 2873-2882. [CrossRef]

120. Reddi, H.V.; Madde, P.; Cohen, Y.C.; Bangio, L.; Breitbart, E.; Harats, D.; Bible, K.C.; Eberhardt, N.L. Antitumor Activity of VB-111, a Novel Antiangiogenic Virotherapeutic, in Thyroid Cancer Xenograft Mouse Models. Genes Cancer 2011, 2, 993-995. [CrossRef]

121. O'Cathail, S.M.; Pokrovska, T.D.; Maughan, T.S.; Fisher, K.D.; Seymour, L.W.; Hawkins, M.A. Combining Oncolytic Adenovirus with Radiation-A Paradigm for the Future of Radiosensitization. Front. Oncol. 2017, 7, 153. [CrossRef] [PubMed]

122. Goradel, N.H.; Mohajel, N.; Malekshahi, Z.V.; Jahangiri, S.; Najafi, M.; Farhood, B.; Mortezaee, K.; Negahdari, B.; Arashkia, A. Oncolytic adenovirus: A tool for cancer therapy in combination with other therapeutic approaches. J. Cell Physiol. 2019, 234, 8636-8646. [CrossRef] [PubMed]

123. Krysko, D.V.; Garg, A.D.; Kaczmarek, A.; Krysko, O.; Agostinis, P.; Vandenabeele, P. Immunogenic cell death and DAMPs in cancer therapy. Nat. Rev. Cancer 2012, 12, 860-875. [CrossRef] [PubMed]

124. Ingemarsdotter, C.K.; Baird, S.K.; Connell, C.M.; Oberg, D.; Hallden, G.; McNeish, I.A. Low-dose paclitaxel synergizes with oncolytic adenoviruses via mitotic slippage and apoptosis in ovarian cancer. Oncogene 2010, 29, 6051-6063. [CrossRef] [PubMed]

125. Topalian, S.L.; Drake, C.G.; Pardoll, D.M. Immune checkpoint blockade: A common denominator approach to cancer therapy. Cancer Cell 2015, 27, 450-461. [CrossRef] [PubMed]

126. Topalian, S.L.; Taube, J.M.; Anders, R.A.; Pardoll, D.M. Mechanism-driven biomarkers to guide immune checkpoint blockade in cancer therapy. Nat. Rev. Cancer 2016, 16, 275-287. [CrossRef]

127. Chen, L.; Han, X. Anti-PD-1/PD-L1 therapy of human cancer: Past, present, and future. J. Clin. Investig. 2015, 125, 3384-3391. [CrossRef] 
128. Wolchok, J.D.; Chiarion-Sileni, V.; Gonzalez, R.; Rutkowski, P.; Grob, J.J.; Cowey, C.L.; Lao, C.D.; Wagstaff, J.; Schadendorf, D.; Ferrucci, P.F.; et al. Overall Survival with Combined Nivolumab and Ipilimumab in Advanced Melanoma. N. Engl. J. Med. 2017, 377, 1345-1356. [CrossRef]

129. Thorsson, V.; Gibbs, D.L.; Brown, S.D.; Wolf, D.; Bortone, D.S.; Ou Yang, T.H.; Porta-Pardo, E.; Gao, G.F.; Plaisier, C.L.; Eddy, J.A.; et al. The Immune Landscape of Cancer. Immunity 2018, 48, 812-830.e14. [CrossRef]

130. Giannini, R.; Moretti, S.; Ugolini, C.; Macerola, E.; Menicali, E.; Nucci, N.; Morelli, S.; Colella, R.; Mandarano, M.; Sidoni, A.; et al. Immune Profiling of Thyroid Carcinomas Suggests the Existence of Two Major Phenotypes: An ATC-like and a PDTC-like. J. Clin. Endocrinol. Metab. 2019, 104, 3557-3575. [CrossRef]

131. Bastman, J.J.; Serracino, H.S.; Zhu, Y.; Koenig, M.R.; Mateescu, V.; Sams, S.B.; Davies, K.D.; Raeburn, C.D.; McIntyre, R.C., Jr.; Haugen, B.R.; et al. Tumor-Infiltrating T Cells and the PD-1 Checkpoint Pathway in Advanced Differentiated and Anaplastic Thyroid Cancer. J. Clin. Endocrinol. Metab. 2016, 101, 2863-2873. [CrossRef]

132. Liotti, F.; Prevete, N.; Vecchio, G.; Melillo, R.M. Recent advances in understanding immune phenotypes of thyroid carcinomas: Prognostication and emerging therapies. F1000Res 2019, 8, F1000. [CrossRef]

133. Cunha, L.L.; Marcello, M.A.; Morari, E.C.; Nonogaki, S.; Conte, F.F.; Gerhard, R.; Soares, F.A.; Vassallo, J.; Ward, L.S. Differentiated thyroid carcinomas may elude the immune system by B7H1 upregulation. Endocr. Relat. Cancer 2013, 20, 103-110. [CrossRef]

134. Cunha, L.L.; Morari, E.C.; Guihen, A.C.; Razolli, D.; Gerhard, R.; Nonogaki, S.; Soares, F.A.; Vassallo, J.; Ward, L.S. Infiltration of a mixture of immune cells may be related to good prognosis in patients with differentiated thyroid carcinoma. Clin. Endocrinol. 2012, 77, 918-925. [CrossRef]

135. French, J.D.; Kotnis, G.R.; Said, S.; Raeburn, C.D.; McIntyre, R.C., Jr.; Klopper, J.P.; Haugen, B.R. Programmed death-1+ T cells and regulatory $\mathrm{T}$ cells are enriched in tumor-involved lymph nodes and associated with aggressive features in papillary thyroid cancer. J. Clin. Endocrinol. Metab. 2012, 97, E934-E943. [CrossRef]

136. Moretti, S.; Menicali, E.; Voce, P.; Morelli, S.; Cantarelli, S.; Sponziello, M.; Colella, R.; Fallarino, F.; Orabona, C.; Alunno, A.; et al. Indoleamine 2,3-dioxygenase 1 (IDO1) is up-regulated in thyroid carcinoma and drives the development of an immunosuppressant tumor microenvironment. J. Clin. Endocrinol. Metab. 2014, 99, E832-E840. [CrossRef]

137. Cabanillas, M.E.; Ferrarotto, R.; Garden, A.S.; Ahmed, S.; Busaidy, N.L.; Dadu, R.; Williams, M.D.; Skinner, H.; Gunn, G.B.; Grosu, H.; et al. Neoadjuvant BRAF- and Immune-Directed Therapy for Anaplastic Thyroid Carcinoma. Thyroid 2018, 28, 945-951. [CrossRef]

138. Iyer, P.C.; Dadu, R.; Gule-Monroe, M.; Busaidy, N.L.; Ferrarotto, R.; Habra, M.A.; Zafereo, M.; Williams, M.D.; Gunn, G.B.; Grosu, H.; et al. Salvage pembrolizumab added to kinase inhibitor therapy for the treatment of anaplastic thyroid carcinoma. J. Immunother. Cancer 2018, 6, 68. [CrossRef]

139. Guo, Z.S.; Liu, Z.; Kowalsky, S.; Feist, M.; Kalinski, P.; Lu, B.; Storkus, W.J.; Bartlett, D.L. Oncolytic Immunotherapy: Conceptual Evolution, Current Strategies, and Future Perspectives. Front. Immunol. 2017, 8, 555. [CrossRef]

140. Liu, Z.; Ravindranathan, R.; Kalinski, P.; Guo, Z.S.; Bartlett, D.L. Rational combination of oncolytic vaccinia virus and PD-L1 blockade works synergistically to enhance therapeutic efficacy. Nat. Commun. 2017, 8, 14754. [CrossRef]

141. Min, I.M.; Shevlin, E.; Vedvyas, Y.; Zaman, M.; Wyrwas, B.; Scognamiglio, T.; Moore, M.D.; Wang, W.; Park, S.; Park, S.; et al. CAR T Therapy Targeting ICAM-1 Eliminates Advanced Human Thyroid Tumors. Clin. Cancer Res. 2017, 23, 7569-7583. [CrossRef]

142. Shaw, A.R.; Suzuki, M. Oncolytic Viruses Partner with T-Cell Therapy for Solid Tumor Treatment. Front. Immunol. 2018, 9, 2103. [CrossRef]

143. Shaw, A.R.; Porter, C.E.; Watanabe, N.; Tanoue, K.; Sikora, A.; Gottschalk, S.; Brenner, M.K.; Suzuki, M. Adenovirotherapy Delivering Cytokine and Checkpoint Inhibitor Augments CAR T Cells against Metastatic Head and Neck Cancer. Mol. Ther. 2017, 25, 2440-2451. [CrossRef]

144. Tahtinen, S.; Gronberg-Vaha-Koskela, S.; Lumen, D.; Merisalo-Soikkeli, M.; Siurala, M.; Airaksinen, A.J.; Vaha-Koskela, M.; Hemminki, A. Adenovirus Improves the Efficacy of Adoptive T-cell Therapy by Recruiting Immune Cells to and Promoting Their Activity at the Tumor. Cancer Immunol. Res. 2015, 3, 915-925. [CrossRef] 
145. Bommareddy, P.K.; Aspromonte, S.; Zloza, A.; Rabkin, S.D.; Kaufman, H.L. MEK inhibition enhances oncolytic virus immunotherapy through increased tumor cell killing and T cell activation. Sci. Transl. Med. 2018, 10, eaau0417. [CrossRef]

146. Raman, S.S.; Hecht, J.R.; Chan, E. Talimogene laherparepvec: Review of its mechanism of action and clinical efficacy and safety. Immunotherapy 2019, 11, 705-723. [CrossRef] 